\title{
第23回 近畿神経病理検討会抄録
}

\author{
平成元年 7 月18日（大阪第 1 ビル） \\ 世話人代表 吉峰 俊樹 (大阪大学脳神経外科)
}

特異な脳梗塞と思われる一例

大阪厚生年金病院 脳神経外科, 将理検查科 長谷川 洋, 尾藤 昭二, 小橋 二郎, 小林 晏

症 例: 74歳, 男性.

主 訴: 左手のシビレ感, 後頙痛.

既往歴：20歳時中耳炎, 肥厚性鼻炎.

現病歴：入院の 4 年前より左手のシビレ感があり, 他 院にて頸椎症と惨断され治療をうけたが，CT にて異常 所見を発見され当院を紹介された.

所 見: 左手学固有筋の atrophy を少め, 頸椎 C 5/6 に後方への osteophyte を涊めた. CT にて右 frontal に mixed density area があり, 造影剂により境界明瞭 均一に enhance された（Fig. 1). CAG で右内頸動 脈の軽度の狭窄と壁不整を涩めた. 頸椎レ線にてて頸椎症 の所見あり.
于：術：開䫄術を行うと，病変は脳実質内にあり弾性

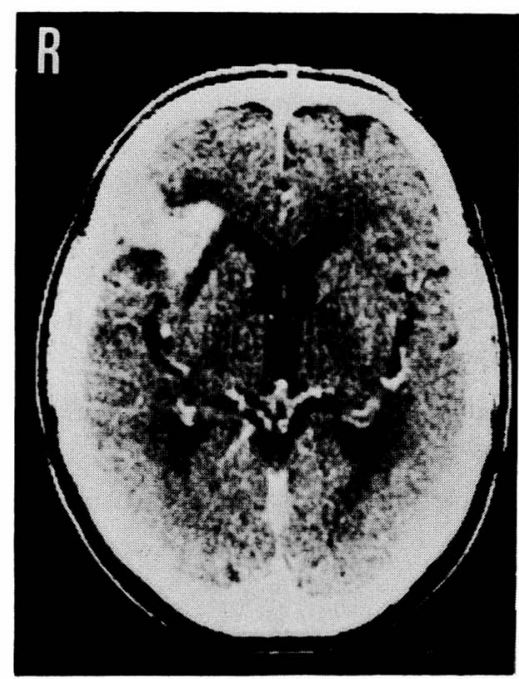

Fig. 1 Enhanced CT

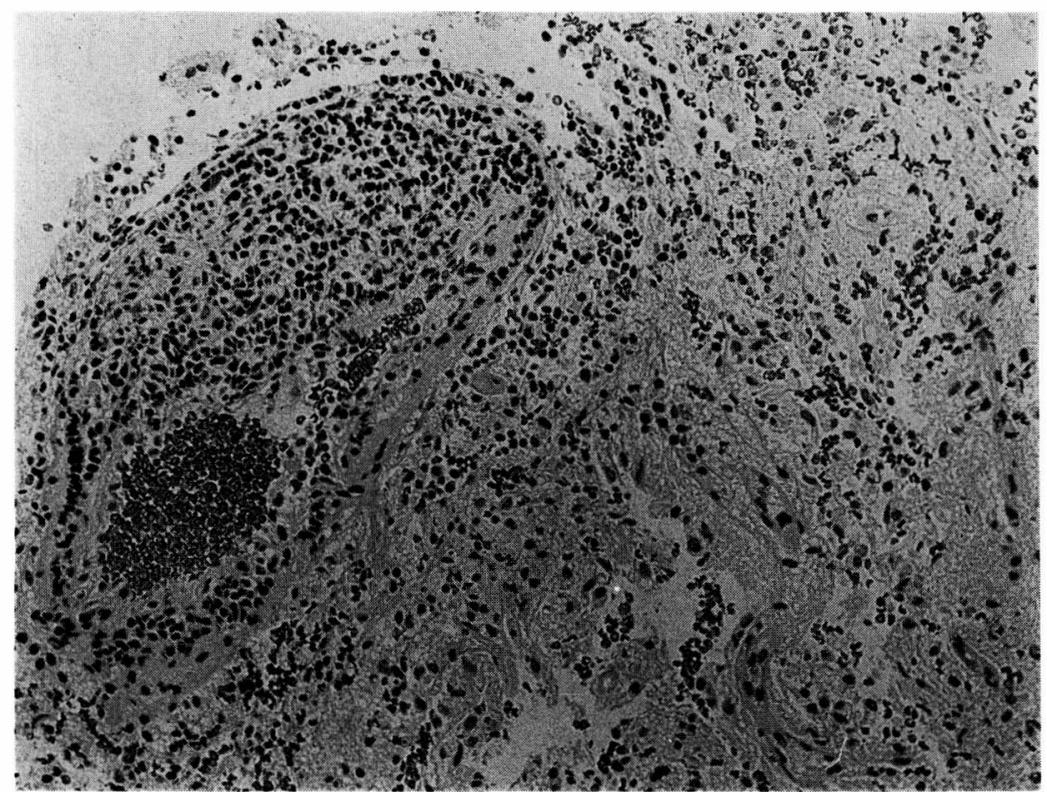

Fig. $2 \quad H \& E \times 200$ 
硬で周辺脳との境界は明瞭であった。

病理所見：病巣は新旧の出血巣を含えでおり,一部に 血管の増殖をみとめるが，何等かの血管奇形や血管腫を 示す所見はなかった. 全体に脸組織は破壞され，foamy cell の diffuse な浸潤を認める. いくつかの血管の周辺 には lymphocyteを主とする炎症細胞の著明な浸潤を認 めるが, angitis を示す所見ではなかった（Fig. 2). これらの細胞の GFAP 染色は陰性で LCA は陽性であ った. また一部の小動脈は fibrin 血栓により閉塞して いた.

Comments : この症例は脳腫瘍の術前診断にて開頭術 を行ったが, 病理組織学的には腫瘍の所見はなく, 脳梗 塞の所見を示した. しかし以下に述べる点において脳梗 塞にしては特異的である，1）梗塞を示唆するエピソー ドがなく，またそれによる症状もでていない，2）CT 上境界明瞭で均一な enhancement を示し, しかも血 管の領域に一致しない部位に存在する， 3 ）手術にお いて境界の明瞭なむしろ硬い組織であった. このため granulomatous angitis のような特殊な原因による梗塞 巣を疑い検索したが，特別な所見は今のところ得られて おらず，何故このような梗塞巣ができたかは不明であ る.

\section{巨細胞性㵦膜腫}

兵庫医科大学脸神経外科

森村 達夫, 横田 正幸, 松本強, 谷栄一

症 例: 56歳, 男性.

主 訴: 右片麻痺.

現病歴：昨年10月頃より徐徐に右下肢, 次いで右上肢 の麻痺に気づく.

入院時神経学的所見: 簏血乳頭, 右片麻瘏 (upper ; $4+/ 5$, lower ; 4/5)

神経放射線学的所見 : (Fig. 1)

CT : iso-slightly high density mass with contrast enhancement, central low density $(+)$ peritumoral edema $(+)$

MRI : iso on T1WI, slightly high on T2WI, Gd. enhancement $(+)$

手 術: 傍矢状洞の実質外腫瘍を全摘出, 洞内腫瘍は 電気凝固した。 (Simpson grade II)

光顕所見（病理標本番号 891790）

vesicular で大小様々の核を有す細胞集団が compart-

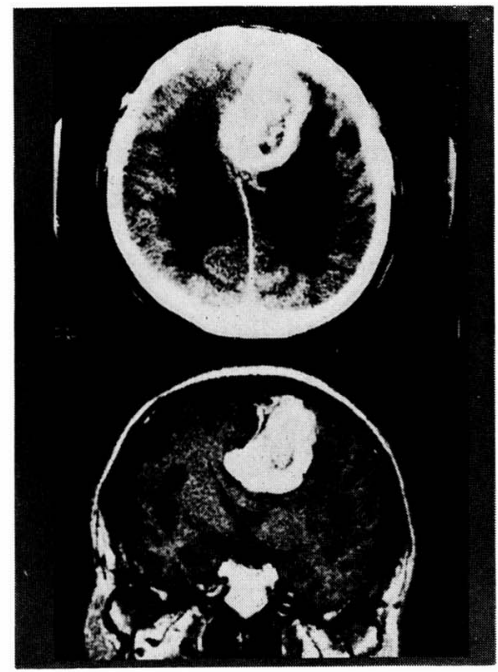

Fig. 1 Irregularly enhanced mass in left frontal parasagittal region on CECT (upper) and on Gd-DTPA MRI. (lower).

ment を形成し，一部では storiform pattern を示す所 も観られる. 巨細胞で nuclear inclusion が観察される. 所々でクロマチンに富さ卵円型の核を有する, 小型細胞 群が密集している. 明らかな whorl formation を認め ず, psammoma body は2 力所で認めた. mitosis は少 なく数視野（X400）に1ケ程度で，軽度血管増殖を認 めた．壊死部を恋めるが術前日の Ivalon による embolization の影響を否定できない. 免疫組織学的には Vimentin (十) Cytokeratin (一) EMA は一部に陽性 所見を認めるのみであった（Fig. 2).

Comments : Meningioma の variant と考えられる. anaplastic meningioma $の$ cytological criteria として分 裂期の細胞が多い, 脸実質への侵潤がある, 壞死の存在, 細胞異型性が挙げられているが, この腫瘍の場合初めの 3 項目を充たさない. しかも anaplastic meningiomaの 最終的な組織像は spindle cell sarcoma であり, 現時点 では malignant meningioma の存在自体を疑う人もい る. 䯣膜腫の診断に際しては whorl formation, psammoma body, interdigitation があれば簡単に組織診断が 可能であるが，本例のように種々の variants があり， 巨細胞性噵膜腫とも呼ぶべき variant も Montefiore Medical Center の上松, 平野等によると131例中 3 例認 めたという報告がある.

本例は術後麻痺も改善し, 放射線治療を受けることな く元気に退院したが, 今後 anaplatic meningioma の存 在を含めて注意深く経過観察したい. 


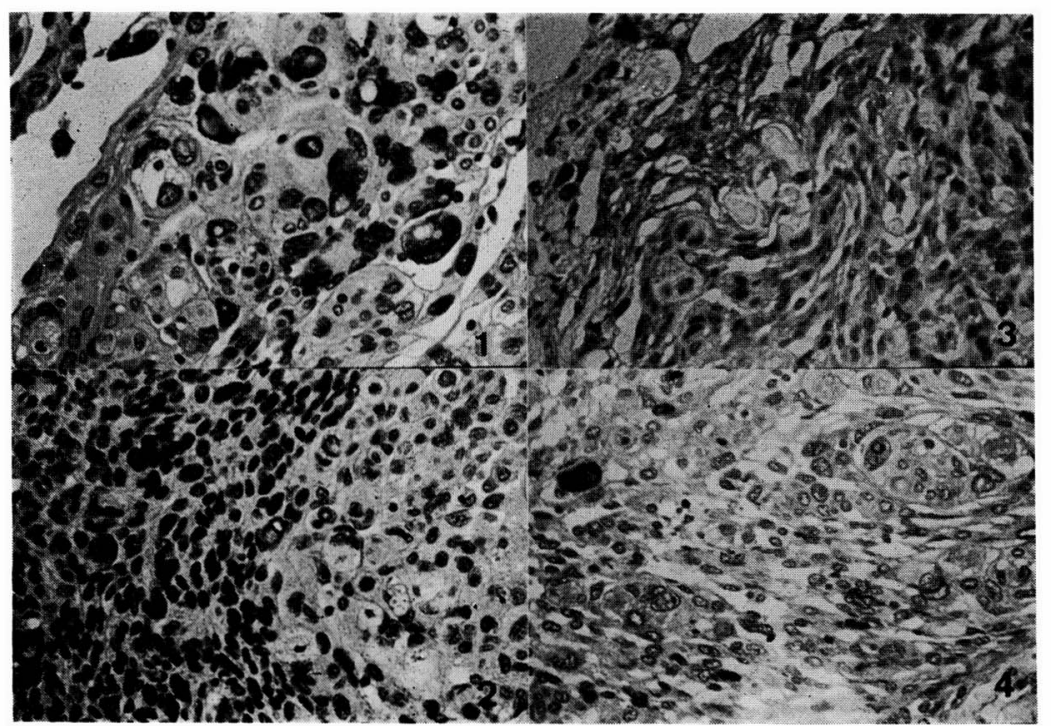

Fig. 2 (1) Nuclear pleomorphism of tumor cells, some of which contain nuclear inclusions. HE X200

( 2 ) Hypercellularity with nuclear hyperchromasia is recognized in the left half. HE X200

(3) There are few focal tumor cells mimicing arachnoidal cell origin, positive for Epithelial Membrane Antigen (EMA). $\mathrm{X} 200$

(4) Tumor cells are diffusely positive for Vimentin, but the stainability are variable. X200

\section{References}

1. Russell DS, Rubinstein LJ : Pathology of tumours of the nervous system. pp. 479, 1989.

2. 上松右二, 平野朝雄：“巨細胞性”とも呼ぶべき Meningioma. 第 7 回日本脳腫瘍病理研究会抄録 集 pp. 48, 1989.

\section{小児期に出血で発症した papillary meningioma}

済生会中和病院兴神経外科

$$
\text { 角田 茂 }
$$

牧方市民病院中検病理部

$$
\text { 堤㤵 }
$$

罧立奈良病院脳神経外科

本多誠, 岡崎 孜難

症 例: 7 歳, 男性.

主 訴: 頭痛・嘔吐.
現病歴：1989年 6 月 8 日, 頭痛あるも翌日には軽快し た. 6 月 17 日, 午前 8 時 30 分頃, 頭痛・嘔吐発作ととも に, 右片麻痺が出現し, 同日入院となった.

既往歴・家族歴：特記すべきことなし.

神経学的所見：意識は 傾眠 (II-10) で, 右片麻痺が 認められた。

CT 所見 : 単純 CT では, 左前頭・頭頂部に皮質下出 血が認められ, 造影 CT (Fig. 1) では, falx meningioma を思わせる, ほぼ均一な増強効果が認められ た。

血管撮影所見：左中硬膜動脈を主とし, 左前大脳動 脈・中大脳動脈より栄養される腫瘍陰影が認められた.

手術所見：両側前頭・頭頂開頭にて腫瘍を亜全摘し た. 腫瘍は, 脳実質とは剝離可能であったが, 大脳鎌と は強く癒着しており, 大脳鎌より発生した meningioma と思われた。しかし, いらもの meningiomaよりやわら かで，易出血性であった.

組織所見 : 腫瘍組織には, 新旧の出血およびそれに対 
する組織反応が認められた，腫瘍細胞は， perivascular papillary formation 形成し増殖していた（Fig. 2). Whorl formation も散見された. 免疫組織化学的には, GFAP 陰性, S-100 蛋白陰性, Vimentin 陽性, EMA 陽性であった.

コメント : meningioma の perivascular papillary formation $と$, ependymoma $の$ perivascular pseudorossette との鑑別であるが, GFAP 陰性で S-100 蛋白陰性とい うことより ependymoma は否定され，Vimentin 陽性で EMA 陽性ということより meningioma と診断された. Ludwin らの報告によると，17例の papillary meningioma の中で， 15 歳以下は 8 例と約半数を占めている. 本腫瘍は，小児に多い meningioma の一亜型と思われ る.

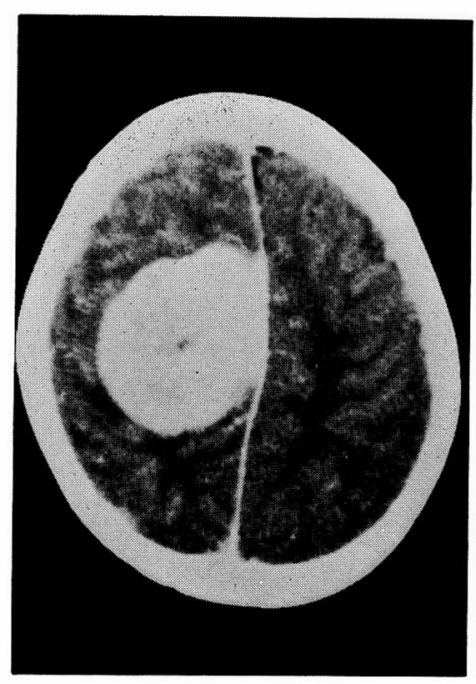

Fig. 1 Enhanced CT showing falx meningioma

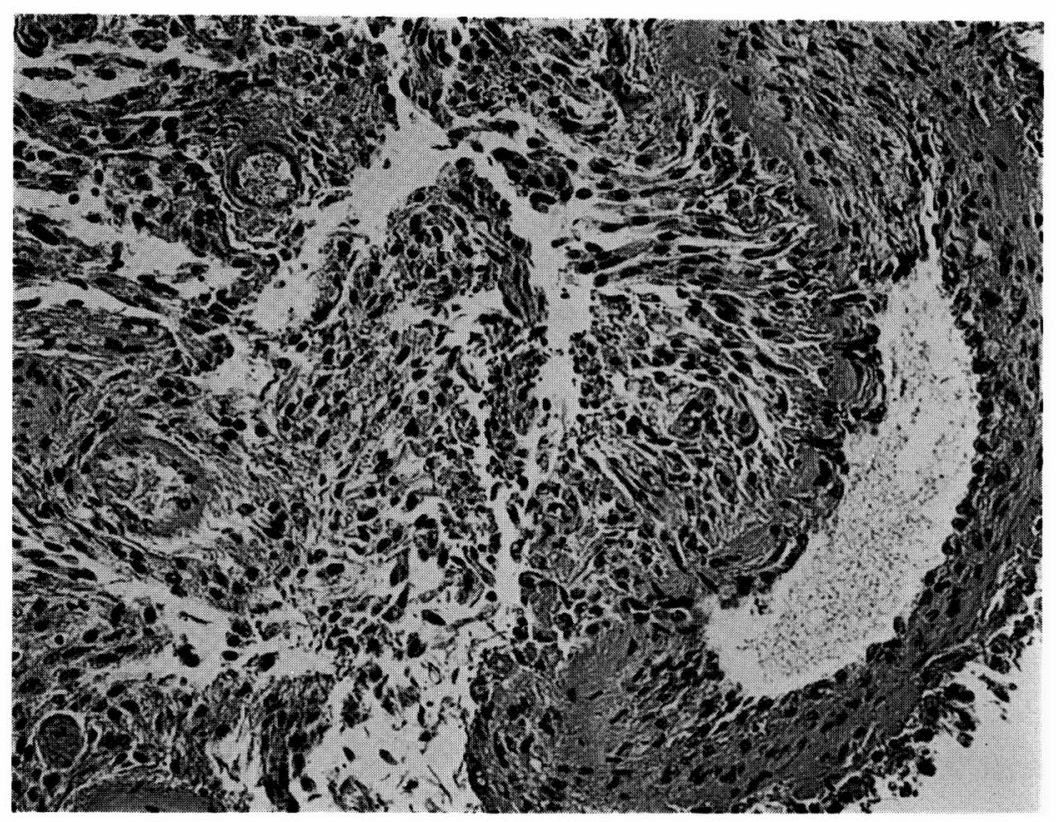

Fig. 2 Perivascular papillary formation suggesting papillary meningioma (H.E. X100) 
形質細胞，小リンパ球及びマクロファージの浸潤像を呈 した intrasellar extrapituitary gland tumor の一例

京都大学脳神経外科

$$
\begin{aligned}
& \text { 山崎 俊概, 菊池 啨彦, } \\
& \text { 橋本 信夫, 高見 昌明 }
\end{aligned}
$$

症 例: 59歳, 男性.

主 訴：右眼䀫下垂.

現将歴：平成元年 3 月28日右眼䀫下垂をきたし，近医 こて CT上の異常を指摘され当科入紹介入院となった.

既往歴：昭和63年 4 月中耳炎（石難聴と耳鳴）

家族歴：特記すべき事項なし。

入院時神経学的所見 : 右動眼神経麻痺, 右難恥.

神経放射線学的検査: CT ではトルコ鞍内に比較的㑽 界鮮明で前方部及び周囲が各々節状とリング状に造影さ れる高吸収域腫瘍を㤎める（Fig. 1)，脳血管恐:では特 記すべき異常所見はない. MRI では TI 及び T2 強調 画像でトルコ鞍内に限局した heterogeneous な病变を惢 め, Gd-DTPA 投与後の T1 強調画像における冠状断 及び矢状断で比較的境界明膫で heterogeneous に造影さ れる腫瘍を恋める（Fig. 1 ).

乎術：平成元年 5 月10日に Hardy 氏手術を施行した。 トルコ鞍内で前方部に限局し，正常の下垂体組織を後うj に压排する境界明瞭な占拠性腫瘍を梁め，顕微鏡下に腫 瑒を全摘した。

光顕所見：状变内には下垂体本来の細胞はみられず,

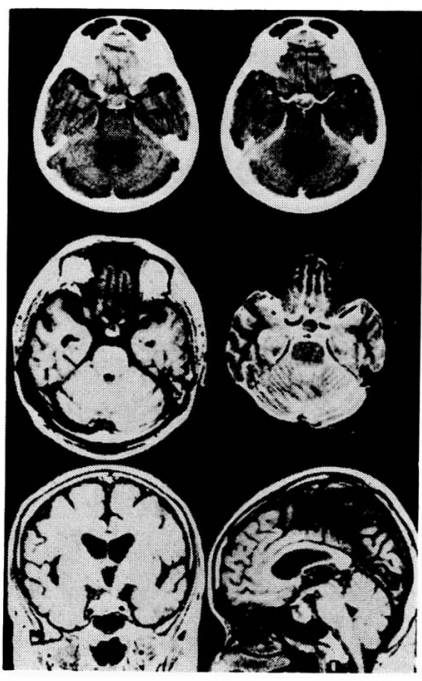

Fig. 1 <神経放射線学的所見>

上段(左)：単純水平断 C T, 上段(右): 造影水平断 C T

中段 (左): 水平断 T 1 強調画像，中段(右)）: 水平 断 T 2 強調画像

下段(左)：冠状断 T 1 強調画像(Gd-DTPA 投与後) 下段(右)：矢状断 T 1 強調画像 (Gd-DTPA 投与後) トルコ鞍内に限局する heterogenous な病変を認め る.

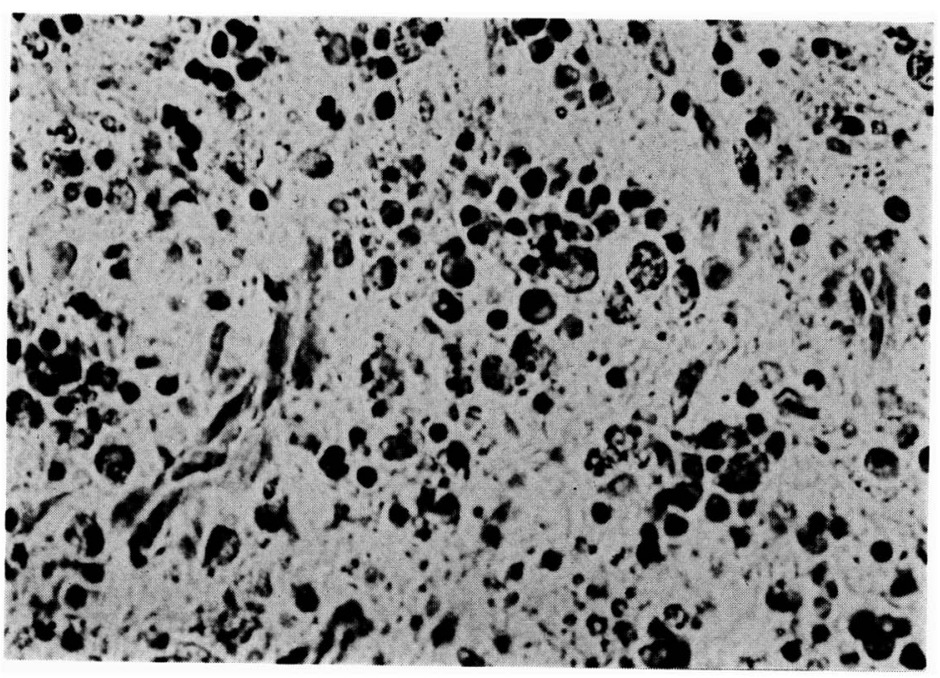

Fig. $2<$ 病理組織所見>

下垂体本来の細胞はみられず，類上皮細胞を背景とした形質細胞， 小リン・球及びマクロファージの浸㵎を認める $(\times 200)$. 
類上皮細胞を背景とした形質細胞, 小リンパ球及びへモ ジデリンを貧食したマクロファージ等の浸潤像を認める (Fig. 2). 明らかな壊死像又は巨胞は認められない.

コメント：病理学的には granulation 又は広義の意味 では granuloma と診断されるのみであり, 炎症後の亜 急性期又は慢性期の組織像と思われる.下垂体本来の細 胞がみられないことから, 自己免疫反応との関連性が示 唆されているいわゆる lymphocytic hypohysitis は考え にくいものと考えられる.

上段 $($ 左): 単純水平断 $\mathrm{CT}$, 上段 $($ 右) : 造影水平断 $\mathrm{CT}$ 中段(左): 水平断 $\mathrm{T} 1$ 強調画像, 中段 (右): 水 平断 $\mathrm{T} 2$ 強調画像 下段 (左) : 冠状断 $\mathrm{T} 1$ 強調画 像 (Gd-DTPA 投与後) 下段(右): 矢状断 $\mathrm{T} 1$ 強 調画像 (Gd-DTPA 投与後)

トルコ鞍内に限局する heterogenous な病变を涊め る.

\section{下垂体茎部に付着した鞍上部腫瘍の一例}

大阪市立大学脳神経外科

勝山 諒亮, 白馬 明

症 例: 58歳, 男性.

主 訴: 頭痛.

現病歴：昭和63年10月初旬より頭痛および頭重感を訴 えるようになり，10月28日に某院を受診し，CT スキャ

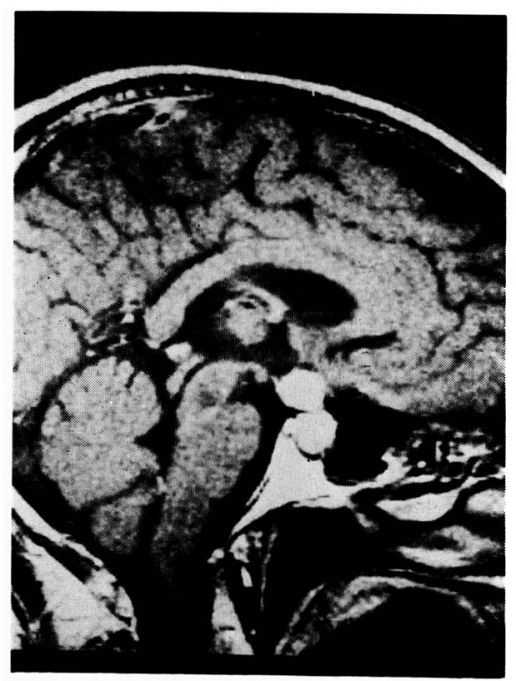

Fig. 1 造影 MRI

(TR $=600 \mathrm{msec}, \quad \mathrm{TE}=40 \mathrm{msec})$

ンで鞍上部に腫瘁を指摘された。

既往歴：30年前に肺結核で入院加䝤.

家族歴：特記すべきことなし。

入院時神経学的所見（平成元年 2 月 10 日）：腋毛・恥 毛の脱落傾向. その他, 神経学的汇異常を認めず.

神経放射線検査所見：CT スキャンで鞍上部にやや high densityで, 造影戍により均一な増強効果を示卞直

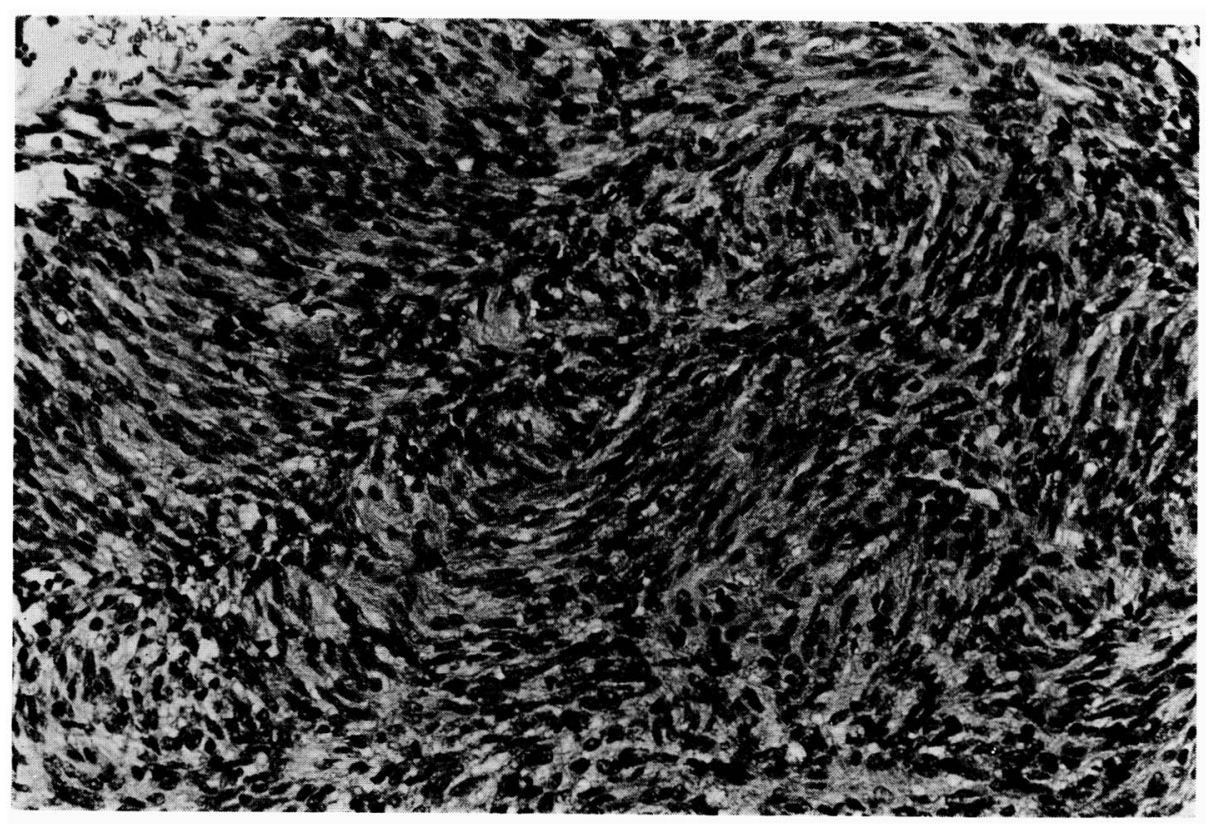

Fig. $2 \mathrm{H} \& \mathrm{E}$ 
径1. $5 \mathrm{~cm}$ の球状の腫瘍陰影が認められた. MRI において 腫瘍は $\mathrm{T}_{1}$ 強調画像で Gd-DTPA により増強効果をう けた（Fig. 1).

手術所見：腫湟は軟らかく易出血性で下垂体荎部に付 着していた.

光影所見 (Fig. 2)：類円形ないし長楕円形の核を有 する細長い腫崵細胞が密に集合し, 束状に種々の方向に 走行する傾向が垫められた。鍍銀染色では, 主に血管の 周囲において細胞間に好銀線維の増生が見られるが、は なれた部位においてはさほど目立たない，免疫組織化学 染色については, S-100 蛋白に陽性, GFAPについては 陰性であった。

電顕所見：細胞は細長い形態をもち，細胞突起間の interdigitation にはそしいが, 細胞間接合装置が散見さ れる. 血管周囲の腫瘍細胞は basement membrane K 囲まれているが，血管からはなれるにしたがい伴わなく なるままた腫瘍組織に隣接して下垂体茎部と考元られる 中枢性㟘道鞘からなる組織が含まれていた。

Comments : H\&E 染色では schwannoma との意見が だされたが，鍍銀染色に抦ける好銀線維の分布様式は典 型的でないとされた，さらに，電顕像からは腫瘍細胞の 配列様式, 特に basement membrane との関係からむし ろ fibroblastic meningioma と診断された. 腫瘍が下垂 体茎部と付着していた点については，同部位のクモ膜を 発生母地とする意見が述べられた。

\section{術後蹃腔構種をきたしたと思われた脳腫瘤の一例}

関西医大脳神経外科

$$
\begin{aligned}
& \text { 河本 圭司, 西村 卓士, } \\
& \text { 松村 浩 }
\end{aligned}
$$

症 例: 63歳, 男性.

現病歴：平成元年 4 月 9 日突然痙卛発作をされて意識 消失を伴う.この直後嘔吐 1 回あり, 約 1 時間後意識清 明となった． CT で脳腫瘍を指摘され当科入院となっ た。

CT, MRI 所見：右頭頂後頭部に造影 CT で heterogeneousに造影される高吸収域と，その周辺部に低吸 収域がみられ, 右より左への軽度正中偏位を認めた。

MRI では $\mathrm{T}_{1}$ 強調で heterogeneous $に$ low-iso densty に, $\mathrm{T}_{2}$ 強調では腫瘍に high density 認めた(Fig. 1.) 手術所見：4 月18日, 腫瘍覀全摘術施行, 腫場は脳表 面に出ており, 硬膜との瘾着はなかった。境界は一部鮮 明であった。

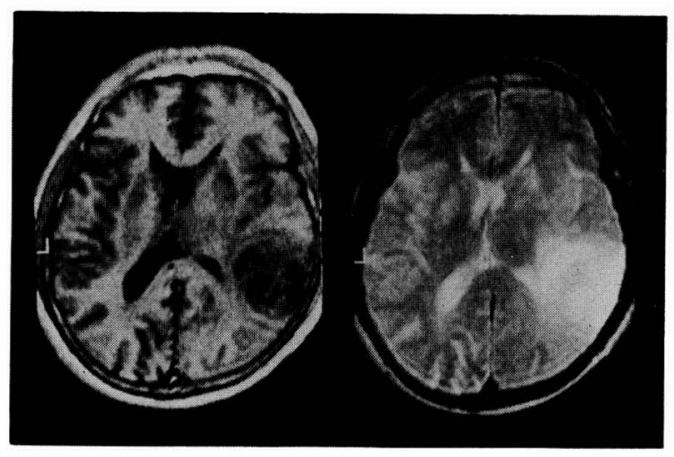

Fig. 1

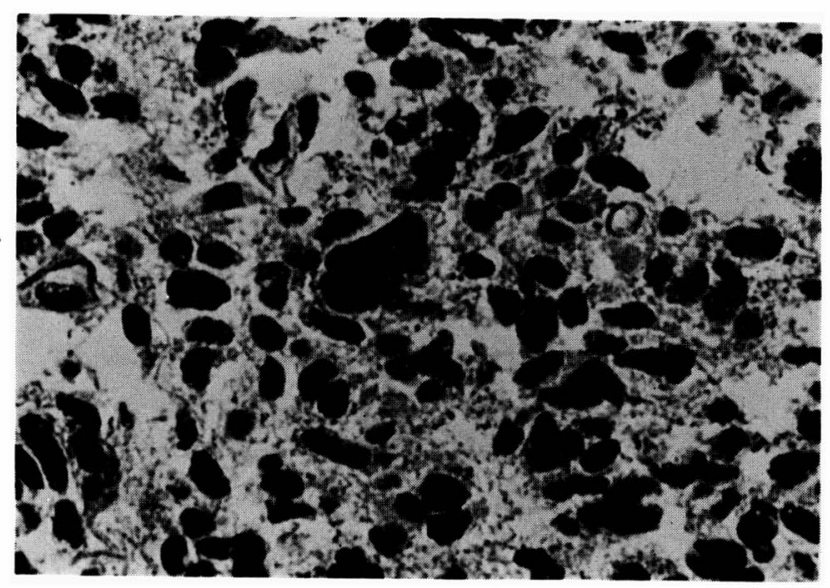

Fig. 2 
術後経過：コバルト照射, ACNU, IFN, OK-432 の 集学的療法を施行した。照射終了時より意識低下し発 熱, 約 1 力月後意識はほぼ清明となる.

光顕所見：核记類円形でクロマチンに富み，やや大小 不同を認め, 細胞分裂像もみられる. cellularity 儿富 み, 血管内皮細胞の増殖も認める. 細胞突起は一部 loose な所で認められる. 一部 perinuclear halo がみられた。 GFAP染色では一部の細胞の細胞質と細胞突起に陽性で あった。 以上の所見より anaplastic astrocytoma と考 えらた (Fig. 2 ).
骨道夜所見：コバルト照射後, 意識低下時の髄液は, や や大型の類円形の核をもつ細胞が多数みられた．組織の

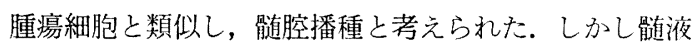
中の細胞を Leucocyte Common Antigen 染色により隰 性であり, lymphoblastic cell と考えられた。

Comments : 組織は一部 peri nuclear haloがみられ, 血 管による仕区りがみられるようで anaplastic oliodendro glioma の可能性の意見も西った. 電顕的検索を予定し ている. 又本例は, 腫瘍細胞と蹃液中の細胞が類似して 混乱したが，LCA 染色が有効な鑑別診断となった。 